\title{
Embodied discourse in the bourgeois museum: performative spaces at the Ordrupgaard collection
}

\author{
Rasmus Kjærboe*
}

\begin{abstract}
In a suburb just north of Copenhagen is Ordrupgaard. At the inauguration in 1918, it was arguably the best collection of impressionism open to the public outside France and the USA. This paper has two goals: First, to reconstruct and analyze the important yet little known original exhibition ensemble at Ordrupgaard, and second, to develop a view of the bourgeois art exhibition as a performative ritual. Building on ideas of exhibition narratives and visitor involvement derived from diverse work done within museology and museum studies, the paper proposes a close examination of how collective memory and performative embodiment drive exhibition experience. From this, Ordrupgaard emerges as an early example of a museum that offers its audience the possibility of a pleasurable enactment of middle class identity within a setting encompassing nature, art and architecture. The case of a small collection museum therefore reveals important mechanics at work within a potentially much larger field of institutions.
\end{abstract}

Key words: Exhibition, bourgeoisie, performativity, impressionism, collection museum

\section{Preliminaries: Arriving at the museum, ca. 1919}

We are taking a trip up north, gradually leaving the noise and bustle of the capital behind as we ride the no. 15 tram-line. Getting off near Bernstorff's Castle, about 10 kilometres from the Copenhagen city centre, we might take a taxi or walk. Since people normally go north for picnics, plenty of carriages are available.

Let us say it is a nice summer day circa 1919. The destination is a mansion on the edge of the large forest of beeches and oaks.

As we pass through the gate and past the home of the head gardener and the large wagon house, everything appears framed and enclosed by the tall trees. The residence itself is far back, at first mostly obscured by trunks and foliage. To the sides we see sheds and greenhouses, glimpse fruit trees and a more formal garden of topiary. Birds are calling, singing, signalling while a distinct smell of grass and leaves fills the air. And now, straight ahead, the house itself bathed in light; a two storey main building with a tall roof and two short wings [fig.1]. The various vines and brambles have not yet filled much of the espaliers on the walls. All seems so very new with the grey-white walls contrasting the overwhelming green of the vegetation and the bright red of the mansard roof. There is a lean and restrained elegance to the ensemble with the surrounding zone of first forest trees, then gardens, giving this place an air of grand retreat.

But the main doors are closed. Today we are visitors; guests without a formal invitation. So it is the elongated, somewhat strange building to the left with its wooden lantern on top that gives welcome. Upon entering, we formally announce our visit by signing the ledger. From the small antechamber follows the first of three exhibition halls. Daylight comes in abundance, the floor is a lightly coloured parquet, the wainscoting a deep reddish brown and the brocade on the walls a dusty greenish violet.

And the paintings we have come to see? The pictures by Manet, Monet, Gauguin, Cézanne and others shimmer bright and colourful as if in direct extension of the pleasures met outside. These paintings - made by artists we read about in surveys of the best, modern 
art (Duret 1906; Meier-Graefe 1907) - truly seem to belong to another, more carefree world. ${ }^{1}$

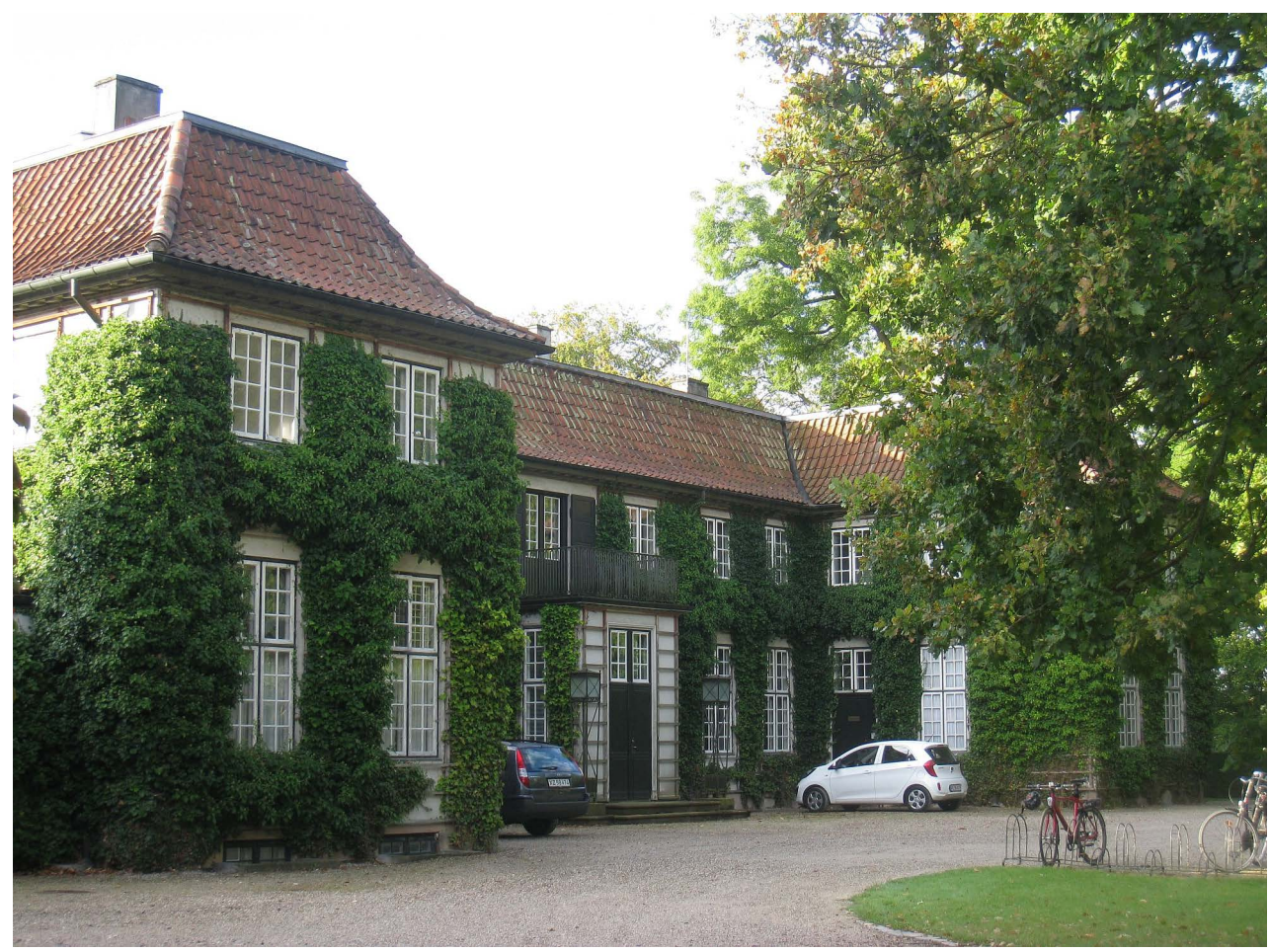

Figure 1. Ordrupgaard, September 2013. Partial view of the original mansion with the French gallery and new wing by Zaha Hadid. Photo: author's own

\section{Why analyze Ordrupgaard?}

As an attempt at a phenomenological description - technically a phenomenological reduction the previous passage would be lacking. In both brevity and dependence on a set of very specific cultural signifiers, it fails to provide a rigorous description from a first person perspective (cf. Gallagher and Zahavi 2008:21-8). Most critical, cultural analyses working from an understanding of the world as perceptually embodied can only hope to suggest the fullness of lived experience. Yet I hope this truncated, largely naïve introduction has hinted at something that should be obvious: namely that any exhibition space is nested within a much larger field of activity and low-level reflection that to a large extent colours and directs experience of that same space.

Today, Ordrupgaard is a public museum under the jurisdiction of the Danish Ministry of Culture. Its holdings comprise two distinct collections of Danish and French art, mainly paintings, from the early nineteenth to the early twentieth century. These were assembled by the Danish insurance director Wilhelm Hansen (1868-1936), who, by the time of WWI, had sufficient means to erect a mansion (1918) in the fashionable Gentofte area on the northern outskirts of Copenhagen. Owing to good fortune and the seemingly depressed prices at the time, Hansen acquired the main part of his first French collection in just over two years, from 1916 to 1918 . The Danish paintings were put up in the semi-private living quarters, while the collection of romantics, realists, impressionists and modernists found a home in a separate but connected wing. Director of the National Gallery and noted art historian Karl Madsen compiled a brief catalogue and gave some assistance to the hanging of pictures (Rostrup 1981; Asmussen 1993; Fonsmark 2011). ${ }^{2}$ The French gallery was inaugurated in September 1918 with a large celebration that attracted the considerable interest of the Danish and Scandinavian press. 
Subsequently, it was open to the general public once or twice a week.

At the time, the quantity and quality of the French collection was seen as exceptional, having almost no equal in Europe outside of France (cf. Madsen 1920; Hedeman-Gade 1921: 2; Dumonthier 1922). The number of pictures by a luminary like Edouard Manet (1832-1883) amounted to nine, with 12 by Paul Gauguin (1848-1903), somewhere from five to eight by Paul Cézanne (1839-1906) and nine by Claude Monet (1840-1926), and with representative works of almost every major French artist of the century leading up to the year 1900, including romantic and realist painters, amounting to a total collection of some 140 pieces; the lack of works by Georges Seurat (1859-1891) and Paul Signac (1863-1935) as a notable exception. In 1922, the unexpected bankruptcy of Scandinavia's largest bank, Landmandsbanken, led to Hansen having to part with about half of his first French collection in early 1923 for which the main buyers were the Ny Carlsberg Glyptotek in Copenhagen, the Swiss Oskar Reinhart (1885-1965) and the Japanese Matsukata Kojiro (1865-1950); a few paintings also went to the American Albert C. Barnes (1872-1951). A second French collection was gradually built up from the ashes of the first, although it never attained quite the same standard (Rostrup 1981, Asmussen 1993, Fonsmark 2011). ${ }^{3}$ Hansen died in 1936, and following the death of his son, Knud Wilhelm (1905-1938), and widow, Henny (1871-1951), the house, gardens and art works were donated to the Danish state as a sort of complete testament to the pleasures of life lead by some of society's most privileged members. Today, the museum includes the private residence and has been extended by the addition of a large wing designed by architect Zaha Hadid (b. 1950) (opened 2005). Every year, a number of temporary exhibitions, mainly focusing on topics directly related to the museum's holdings, are held in collaboration with major, international collections.

A lot can be learned from a close scrutiny of Ordrupgaard's French gallery and the original integration of furnishings and paintings: as exhibition design it is historically situated in an interesting, intermediate period between the densely hung and heavily decorated galleries of the nineteenth century and the emergence of the high modernist "white, "neutral" container' (Klonk 2009: 138) of minimal interior fittings. Much of the original surroundings remain undisturbed, and the total ensemble presents such a unified vision, which makes the historical gallery, mansion and grounds a prime example for investigating the development of strategies of display and museal framing. Finally, and because of this clarity, Ordrupgaard is a case well suited to the ultimate aim of this article; to further understanding of the way that exhibitions and visitors performatively work together in order to create meaning and experience.

Having identified Ordrupgaard as a site of research interest and a suitable case for further study, the remainder of this article will aim to find answers to the following interconnected questions: What kind of exhibition was Ordrupgaard in its early years? What - ideally - were the ideas communicated and the functions fulfilled? How may the way ideas and functions came together in actual experience be explained?

In the next three sections, the exhibition as it looked in the period from 1918 to 1922 is analyzed on the basis of available photographic and textual evidence. The both concrete and conceptual frame created around Ordrupgaard is discussed in relation to three pairings of 'new/old', 'nature/culture' and 'public/private', and examples of the visual programme expressed in the wall hangings are commented upon and put in relation to a programme of modernity and individualism.

A fourth section discusses the intersecting spaces at Ordrupgaard and how the quintessentially 'modern' sites of impressionism are invoked in tandem with a ritual programme. This leads to the fifth section, which approaches the question of how an exhibition programme gets actively enacted by visitors rather than just received and mirrored, in a discussion of performativity, embodiment and experience in the gallery space.

\section{The look of Ordrupgaard}

There are good sources relating to the original incarnation of Ordrupgaard and its French gallery: both mansion and gallery wing stand with only minor alterations, having recently been faithfully restored, and the architectural plans made by Gotfred Tvede (1863-1947) together with a contemporary photographic record are available. Along with a published catalogue 
from the period (Madsen 1918) and limited archival material regarding the partial sale, there are a fair number of contemporary newspaper and magazine articles that, though far from expressing any independent academic evaluations, do give an impression of the impact of the place. ${ }^{4}$ The incomplete private correspondence of Wilhelm and his wife Henny is, in contrast, almost without reference to the gallery. This leaves us with the possibility of a fairly detailed reimagining that nevertheless has very little to say about overt intentions on a personal level. In this and the following two sections, I will therefore use the available material to interpret and discuss a few ways that specific meaning is generated at Ordrupgaard. By discussing this and by linking to larger societal discourses outside the museum, a cluster of closely related intentions should emerge that, if not verifiably relatable to Wilhelm Hansen as an empirical, historical being, are quite clearly identifiable as working within his museum.

So, we are back in 1919 in the halls of Wilhelm Hansen's three room museum [fig. 2-6]. Or rather, we are in his privately curated challenge to the state museum. Unlike the large public collections of art and cultural objects, we have not climbed any imposing stairs, we are on the ground floor, we are surrounded by sumptuous materials and furniture that signify private luxury rather than stately gravitas, and we are immediately able to orientate ourselves in the architecture which possesses a more intimate scale closer to normal living space. And furthermore, we are surrounded by the very art that - still at this time - has little place in the official displays of public Danish museums (Larsen 2002): French plein-air paintings, impressionism and post-impressionism. ${ }^{5}$ As noted in the press at the time, this is something different:

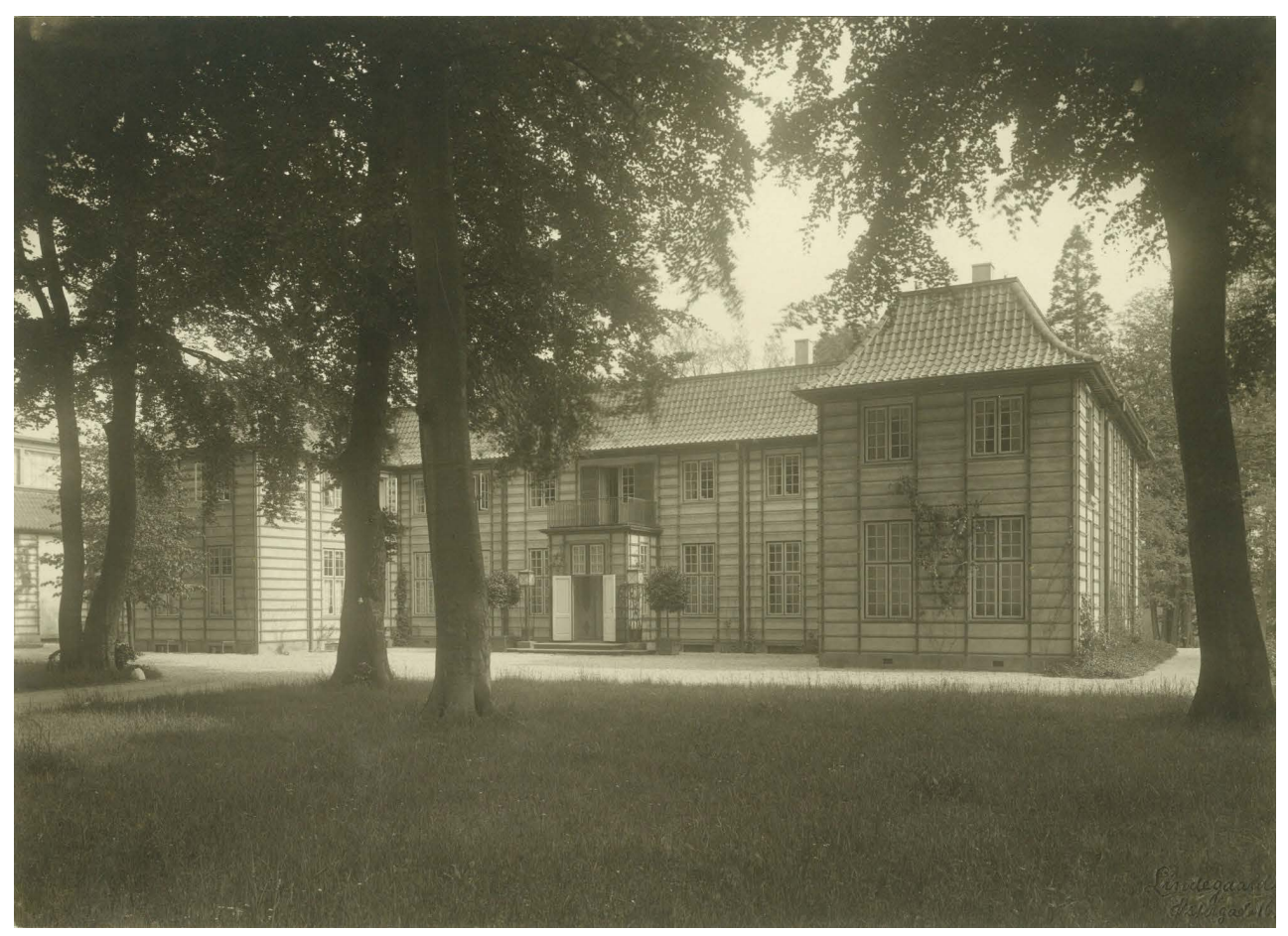

Figure 2. The Ordrupgaard mansion, 1921. The gallery wing can be spotted on the far left. Photo: Lindegaaard 
One should not use the word museum about these three wonderful halls: discreet rugs, a table in the middle with renaissance chairs covered in red upholstery, a renaissance cupboard, old oak benches here and there, and in the last room the low book cases of mahogany - any monotony is banished, there is no museum character, and the collection achieves an intimate, home-like feel that unites the pictures into a quiet whole. (Anonymous 1918)

Another article states that the gallery is, '[...] no dead museum, but a home where the pictures are displayed as in the halls of a patrician' (Haagen 1918). In the character of a home with its furniture, rugs, plants and chandeliers, as well as in other regards, Hansen's gallery closely follows the international trend of the private collection museum of the Belle Époque and later decades as noted in art historian Anne Higonnet's recent survey of the field (Higonnet 2009). ${ }^{6}$

Imagining - for the time being - that we are culturally competent people of or aspiring to the middle class of 1919, we are semiotically speaking able to 'read' Hansen's large villa, the grounds and the exhibition hall as the bourgeois ideal both aggrandized and made concrete. Everything is of course larger, more expensive, more precious. The dream of present and modern

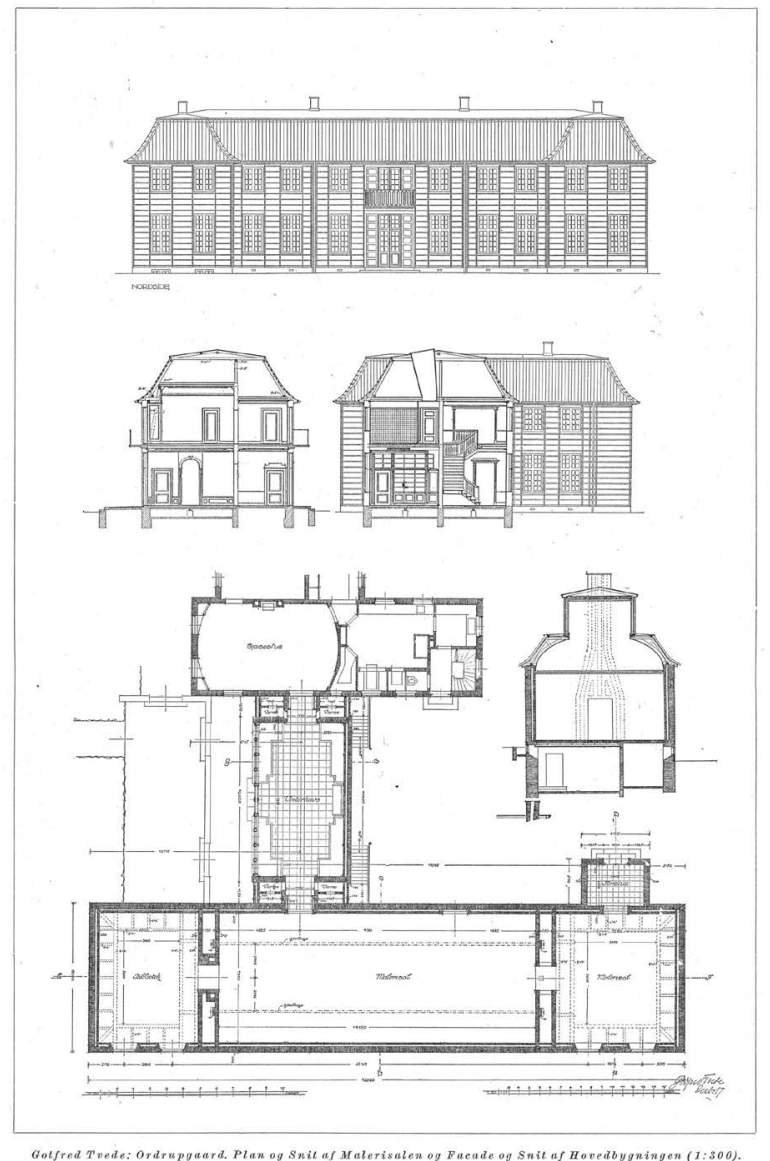

Figure 3. Plan of Ordrupgaard's gallery wing by Gotfred Tvede. Source: Architekten (1921) 23 (13) leisurely bourgeois life is a vision also strongly expressed through photo spreads and texts about Ordrupgaard in several illustrated life style journals from the period. The park is 'as cosy as it is grand [...] a noble frame for an artful home' (Anonymous 1921a), the mansion is 'beautiful and with style [...] equally noble and artistic' (Anonymous 1921b), concluding that:

Ordrupgaard is that Danish home where wealth and good taste has created a harmonic and appealing whole; a lovely old park and a house that unites all the modern demands of a new age with the cosiness that comes from beautiful old furniture and delightful artworks. (Levy 1921)

Architecture, garden and furnishings in the exhibition halls simultaneously connote modernity and a vague and generalised feeling of something past - of tradition though without adhering strongly to any one style. As an example, the historic tables and cupboards are generically 'renaissance' and 'baroque' in form, ${ }^{7}$ the façade and layout of the mansion relate to neoclassical idioms and the park and gardens refer to those surrounding older manor houses. Even the concept of keeping Open House could be seen as a nod to the habits of the British landed aristocracy (Haagen 1918). ${ }^{8}$ Furthermore, the mansion is situated in the former royal game park, in an area filled 


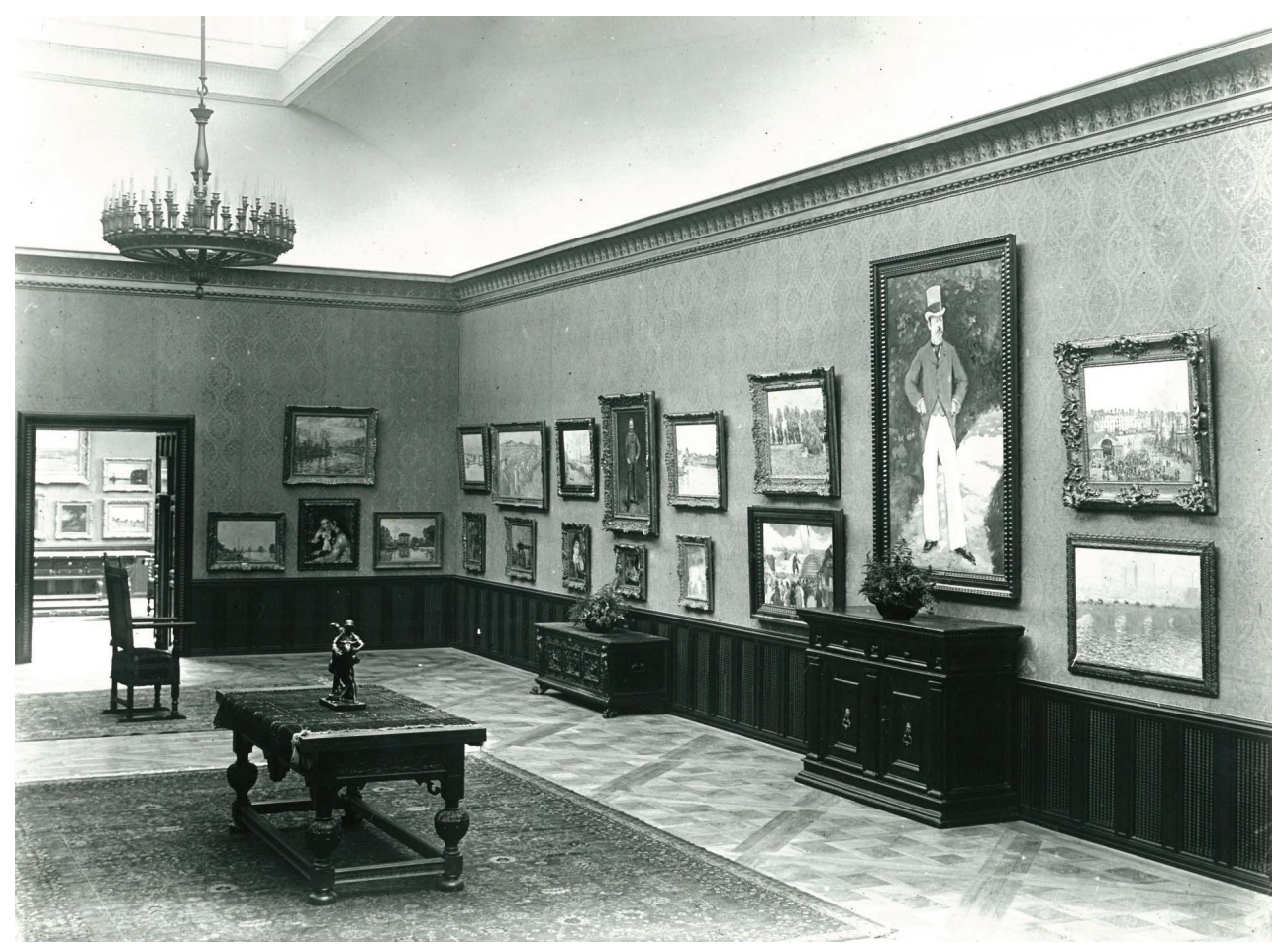

Figure 4. The central hall of the gallery wing, 1918. Manet's painting of Monsieur Brun is surrounded by a set of other canvases; clockwise from top left: Claude Monet: Le meule de foin, 1885, oil on canvas, Ohara Museum of Art, Kurashiki. Edouard Manet: Monsieur Brun, 1879, oil on canvas, National Museum of Western Art, Tokyo. Camille Pissarro: La poisonnerie à Dieppe, 1902, Collection Wildenstein. Claude Monet: Waterloo Bridge, temp gris, 1903, oil on canvas, Ordrupgaard. Edouard Manet: Le depart du bateau de Folkstone, 1869, oil on canvas, Sammlung Oskar Reinhart, Winterthur. Photo: unknown

with dwellings of the aristocracy. In contrast to this mild ambiance of respectability, peerage and solid taste, Ordrupgaard also displays the ever-present feeling of newness, of something bought, and of something methodically assembled and put together with care. This is not simply an expression of inherited wealth; this is the house of a self-made man. And of all the restrained signifiers of castle or manor house contrasting with bourgeois newness, none is more significant than the presence of the paintings gallery. Here ideology is supported by aesthetics in the most deliberate way: From the discreetly modern villa in Ordrup a long historical line stretches back to the galleries of aristocratic and princely collectors of the past, or - closer to home and the present day - to the several royal galleries at Christiansborg Palace (cf. Villadsen 1998). But the actual content of Hansen's gallery engenders references that are explicitly of the dominant class of a more recent era.

\section{Three signifying pairs}

In an influential text first published in 1957, the cultural theorist Roland Barthes described bourgeois values as a pervasive, self-effacing ideology, a system of 'myth' (2009). In his wellknown analysis, a myth distinguishes itself - along with many other operations - by the way that a potentially very wide number of things perceived will, again and again, lead to the same, rather fixed number of associations (Barthes 2009). Visiting Ordrupgaard, this overarching 
bourgeois worldview seems to exist in an ambiguous relationship with another and older code of nobility that it explicitly rejects yet implicitly borrows from. While the idea of aristocracy is largely based on family inheritance and blood lines, the middle class is all about the competency of the singular individual. Still dependent on ideas of eminence, though suspicious of entitlement, the meaning taken from a bourgeois mansion like Ordrupgaard therefore strikes a balance between previous and present codes; or, more simply stated, between the old and the new. This seems to be a significant, subconscious dream of bourgeois mythology: To achieve connoters of aristocracy, and therefore distinction, yet for this to be layered in newness so as to clearly be the just reward for the real and present abilities of the individual. But then again, new/old is just one of several streams of signifying elements leading back to the same ideology of the ruling middle class.

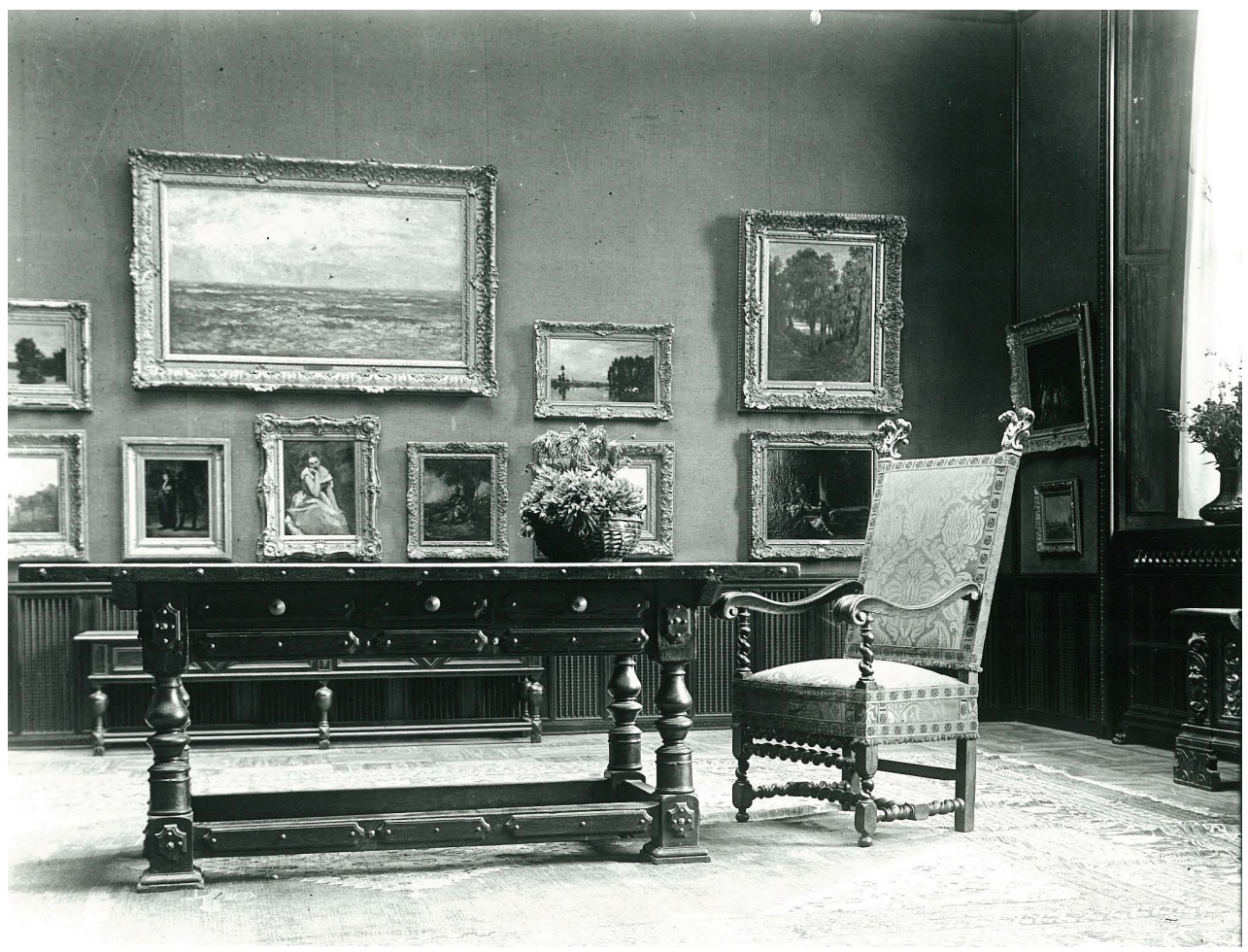

Figure 5. The first hall of the gallery wing, dedicated to romantics and realists, 1918. Photo: unknown.

Complementary to the important signifying pairings of new/old that we see in furnishings, architecture and gallery, another cluster of meaning is expressed around the classic nature/ culture divide. Just as with the previous example, these terms are equally fluid, being variously co-dependent and opposed: progressing from city centre to the so-called villa-towns of the northern suburbs, we experienced a gradual change in urban density and an increase in number of conventional signifiers of Nature until we came to the edge of the Dyrehave forest itself. The park-like atmosphere of the approach to Ordrupgaard with its tall trees simply intensifies this operation. The façade of the main building and the gallery appear in glimpses between the trees, and the same shimmering effect continues in the unusual wooden trellis covering the buildings as support for climbing vines and rose bushes. The outer walls themselves seem to serve as a membrane, a conduit between nature and culture, and as we walk through the exhibition this interplay is echoed in the paintings themselves with their subjects of nature. 
The entirety of journey to and visit in the gallery becomes the deployment of various signifiers of nature and culture in dialectic mediation.

Although a both ancient and contested dichotomy (Lévi-Strauss 1969), the NatureCulture concept takes on a particular romantic significance in the bourgeois era. Looking more closely at Ordrupgaard, it is obvious to see the analytical pertinence of ideas like this, but also to adopt a sceptical, much more fluid approach than in a classical anthropological sense. To illustrate, it quickly becomes evident how Nature - as the most pressing of several metaphors - and also nature - as so many real objects - are just floating signifiers with continued shifts in status and function (Derrida 2001). Both romantic wooded park and formal rose garden surround the mansion, for example, and in the halls pictures of dramatic seascapes mingle with cosy river views, as do ordered garden scenes with wild, mystical forests. Man's shifting and contingent attitudes to the concept and its role as signifier becomes clear as Nature is shown as opposed to, expressive of, or even embodying the pinnacle of culture. Nowhere else is this clearer than in the approach to wood as material and its metonymical changes: At Ordrupgaard, wood can be found as massive tree trunks in the park, in the rough planks of sheds, as geometric espaliers on the façades of gallery and mansion, as highly finished carpentry in the exhibition halls, and finally as a recurring motif in paintings. Jumping from state to state, wood is explicitly transfigured away from the just tangible and into a realm of

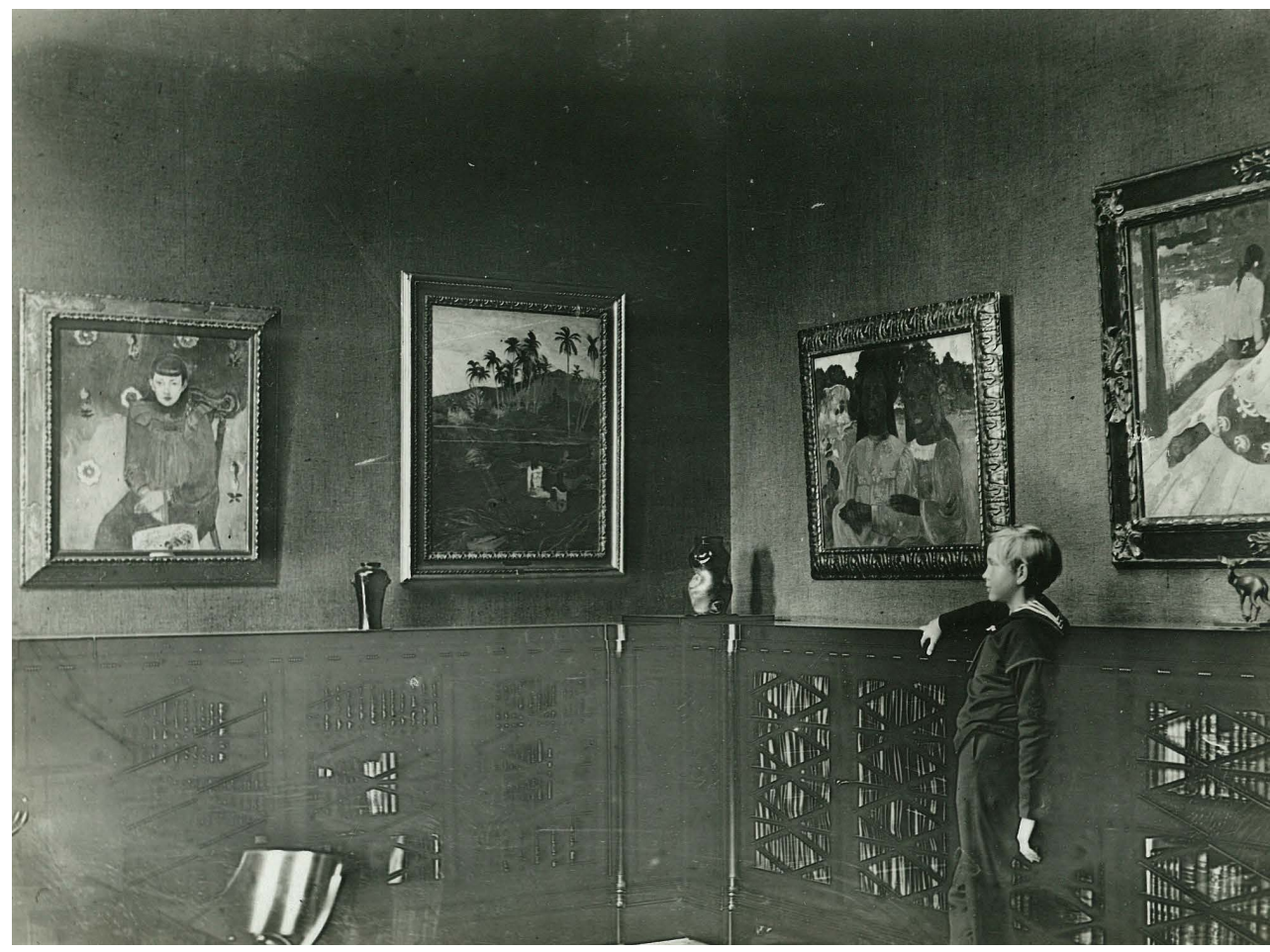

Figure 6. Knud, the son of Henny and Wilhelm Hansen, in the third and last hall of the gallery wing, dedicated to Gauguin and Cézanne, 1918. From left to right: Paul Gauguin: Femmes près des palmiers, 1891, oil on canvas, private collection. Paul Gauguin: Mère et fille, 1901-1902, oil on canvas, The Walter H. and Leonore Annenberg Collection, Metropolitan Museum of Art, New York. Paul Gauguin: La Sièsta, 1892-1894, oil on canvas, The Walter H. and Leonore Annenberg Collection, Metropolitan Museum of Art, New York. Photographer: unknown. 
ideas of Nature and culture. Equally, wood serves as a framing device to direct and guide attention to other things (Entman 1993): Framing happens via the screen of trees in the park as well as in the gilded picture frames, lacquered floors and stained wainscoting. This fluid way in which wood serves as both conceptual and physical frame is just one aspect of how the more composite idea of Nature functions in many different ways at Ordrupgaard. Nature is here seen as the material and vessel through which culture manifests itself and is carried forth rather than being a diametrically opposed value inside a fixed system of values.

Yet a third axis besides new/old and nature/culture presents itself in the already intimated pairing of public/private. Understood as twin concepts, public and private have great signifying power even though often deployed in deliberately ambiguous ways: As an example, the Wilhelm Hansen collection is private, yet open to the public, and while the gallery wing is open to the public, the rest of the house is private. The home and the largely absent Hansen family seem definitely private, yet the public is invited inside both the villa and its daily life through their imagination aided by several features in the press. And when walking the gallery, the tension inherent in the feel of private home made public contributes decisively to this experience. The German philosopher Jürgen Habermas has influentially shown how separations into public and private are an important part of bourgeois (bürgerlich) ideology - and modernity as a whole by extension (Habermas 1991: 27ff). Labels of public and private demarcate areas of different activities in modern society at large, even entering the home where zones are demarcated as more or less accessible to outsiders; as is indeed the case with a large house like Ordrupgaard and its gallery meant for many different levels of semi-public representation. As the historical promise of a free public sphere of open debate, at least according to Habermas, was betrayed through complex developments in the nineteenth century (Habermas 1991: 140ff), the basic distinction of public-private remained in force. Taking a darker turn, later modernity itself might be characterized as a, '[...] sharpening polarization of social life between an increasingly impersonal "public" realm (of the market, the modern state, and bureaucratic organization) and a "private" realm of increasingly intense intimacy and emotionality (the modern family, romantic love, and so forth)' (Weintraub 1997; also cf. Perrot 1990). In this regard, Ordrupgaard could also be seen as recognition of this division between public and private and as an attempt at bridging the gap.

The emotionally grounded, private setting of mansion and gallery could therefore be characterized as another way of engaging with the public sphere than in the rational discourse initially held out as the promise of a future, thoroughly realized bourgeois society. The homely setting of Hansen's gallery, associated as it is with private and deeply felt emotions, becomes a rhetorical device to claim personal sincerity rather than objective rationality as the driving factor of the exhibition. Visitors sign the ledger and in so doing become more like individual guests than anonymous members of a modern, defaced public, and they are consequently asked to suspend any publicly-associated, distanced and traditional museum-going habits they might possess. All the pleasures of the gallery are underpinned by a strong personal appeal that is built upon the skilfully exploited distinction between public life and private existence.

The largest and most central canvas in the middle hall initially attracts the most attention (W. 1918; Gold 1920) - Manet's portrait of Monsieur Brun (1879, National Museum of Western Art, Tokyo) - and becomes like a substitute of the collection owner himself [fig 7.], a kind of avatar created by the hand of arguably the most important artist of the exhibition and its arrangement (cf. Fåhræus 1918). In the linking of portrait and collection both intertwine and become hard to separate. The owner 'is' his collection (cf. Higonnet 2009: 126-127; cf. Baudrillard 2005: 97, 114), and distinctions between private/public are deliberately vague. As a hybrid of traditional full-length portrait and modern gentleman, the painting shows the same bourgeois co-optation of aristocratic codes in the pairing of new/old as seen in architecture and furnishings. The cultured Monsieur Brun seems to step forth from a background of natural, dense foliage - the nature/culture divide in dialectical mediation. In the conflation of various ideas and codes a strong synecdoche emerges where actual portrait (the canvas by Manet) and conceptual portrait (the whole of collection, gallery and context) work together: this is my appeal to you - the whole of me; public and private; nature and culture; new and old; in one.

This intimate appeal felt all through the gallery is not quite the same as Habermas' ideals of a culture of debate between equals, though, since neither Hansen nor family appear 


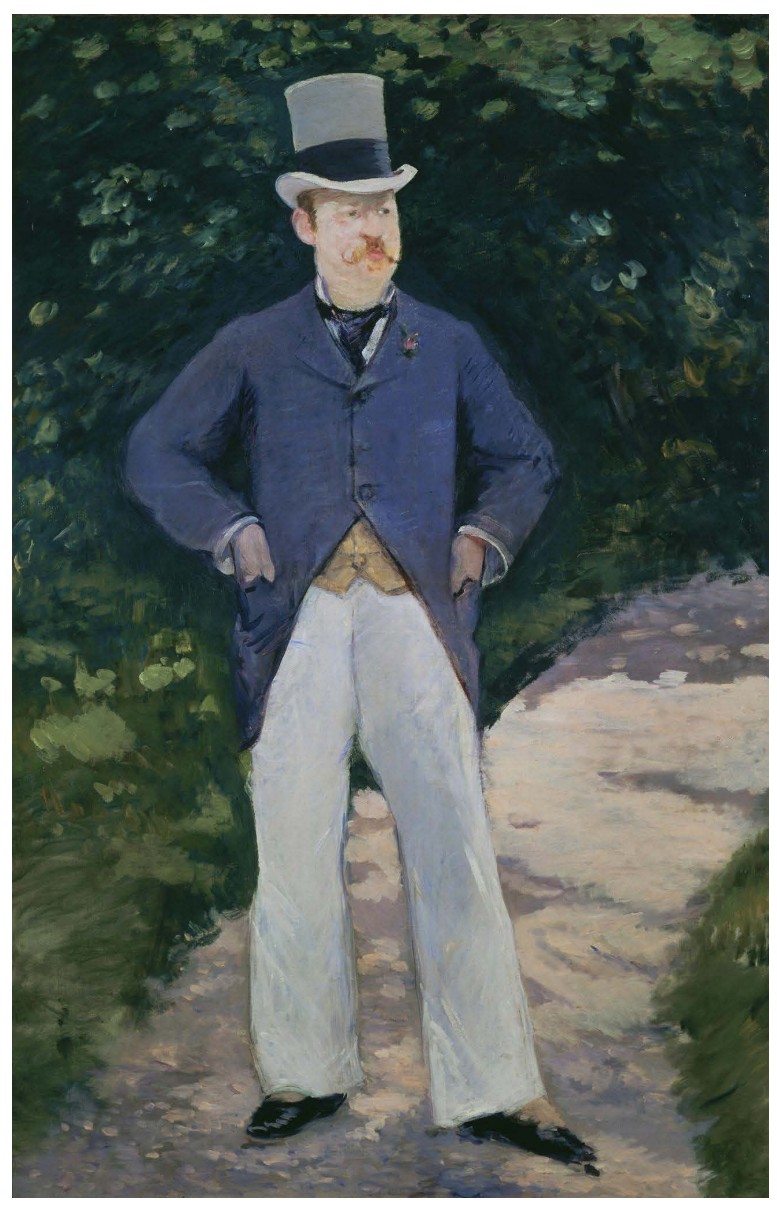

Figure 7. Edouard Manet: Monsieur Brun. 1879. Oil on canvas. National Museum of Western Art, Tokyo as real partners in discussion. Instead of a back-and-forth textual or verbal exchange it supplies a sensual, embodied, spatial discourse which is much different from the pages of the free press or any gentlemanly 'debating club'; an experience neither dialogic nor truly monologic since it clearly demands participation but without argumentation. Ordrupgaard is a place nominally open to all, free of charge, and is indeed democratic in this sense, but in its theatrical character it transcends the true reciprocity of private middle class sociality and approaches the role of an institution as so many other institutions in the modern state.

\section{Visual programmes of modernity}

Taken together, the three pairings of new/old, nature/culture and public/private are resonating parts of a visual rhetoric that, for want of a less laden word, I have here named 'bourgeois'. Adding to this, a number of sub-themes can be found throughout the arrangement of the exhibition and its artworks. Notably, most of the paintings seem to be arranged in distinct groupings that serve to isolate the viewing experience, with each set having its own narrative. Around Monsieur Brun hangs a tight symmetrical arrangement of four paintings [fig. 8] before a wider gap in the hanging directs attention to the next set consisting of a central Manet portrait, this time of Isabelle Lemonnier au fichu blanc (1879, Ny Carlsberg Glyptotek, Copenhagen), surrounded by associated paintings [fig. ], then a further set ... then a further. This rhythmical ordering appeals to the aesthetically educated visitor's desire to move close to inspect single paintings then back to see the whole group, then close again, then back again. The continuous engagement of different viewpoints that each offer their pleasures, something that could be classified as moving between positions 'proper' to the painting and 'overly distant' (Elkins 1999: 16-17), similarly serves to underscore the individuality of the spectator who moves. This isolation has close affinities to the later high modern exhibition arrangement typified by Brian O'Doherty as one privileging a free-flowing eye in continuous space (O'Doherty 1999: 15-16), but with the important distinction that the guiding architectural frame of the exhibition space (Whitehead 2012: 91-92) is not yet whitewashed and its materiality negated.

The individuality of the viewer as a consumer of aesthetic impressions is both presupposed and furthered by this arrangement in sets. Additionally, the thematic centrality of individualism is heavily emphasized through an arrangement where the paintings seem to serve as specific character studies: Monsieur Brun, for example, surveys and controls the land- and cityscapes surrounding him, three of which include water and travel as central themes, all four reflections 
of human activity and industriousness in farming, fishing and commerce. Isabelle Lemonnier, meanwhile, is implicated in an exchange with the calm waters of the Canal du Loing on one side and a tempestuous coastal scene on the other, the contrast explicit enough to be seen as a gendered commentary on the personality of the woman - or women in general - before the eye finds rest in the sensuous fruit basket directly beneath the portrait: any erotic connotations no accident. And if this appeal to the activity of scanning in pairs and groups has not been clear enough, then the rhythmical disposition and remarkable symmetry of male and female portraits ensures that we do not treat each painting as isolated but as statements in larger, syntactical series.

In explicating this kind of close reading of how art works are arranged and juxtaposed, I am indebted to writings by the cultural theorist Mieke Bal, in particular her short, well-known essay on the museum as discourse (Bal 1996). With Bal, we might see the choice of distributing portraits throughout the exhibition halls, instead of gathering them in one section for example, as a specific narrative choice. Small bundles of associations, rather than one epic narrative, are played out, each bundle with a perspective centred on the character presented. Using a more narratological term, this perspective could be identified as the function of focalization placed with variously this or that portrait (Bal 2002: 35-46; Bal 2009: 145-165). While Brun and Lemonnier therefore focalize their respective sets, yet a second order of focalization rests with the originator of the exhibition. At this point, it would probably be too simplistic to search for any one person as this origin, instead identifying the position as second-tier-focalizer as belonging to middle class modernity in its broadest sense. From this perspective, the whole

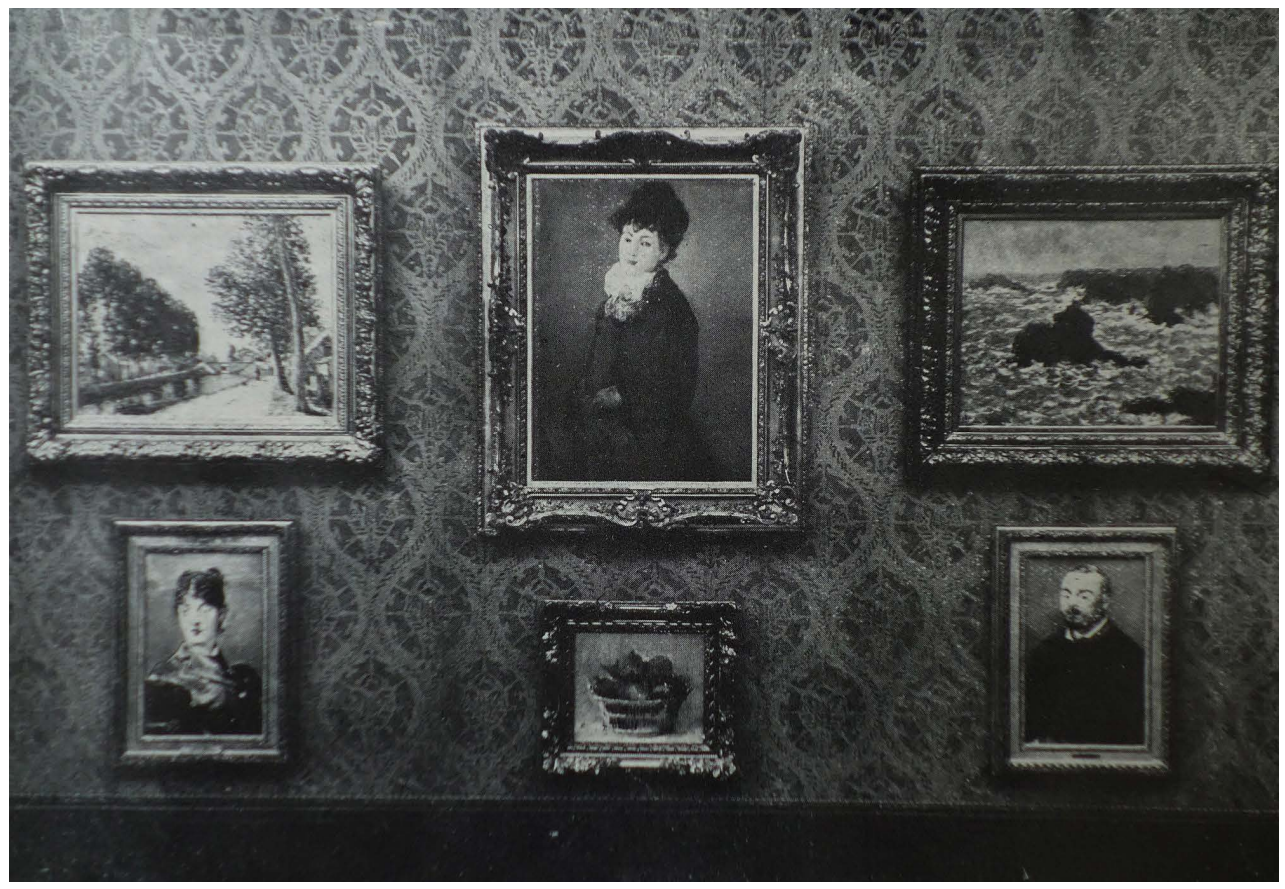

Figure 8. Clockwise from top left: Alfred Sisley: Le canal du Loing à Moret, 1892, oil on canvas, present whereabouts unknown. Edouard Manet: Isabelle Lemonnier au fichu blanc, 1879, oil on canvas, Ny Carlsberg Glyptotek, Copenhagen. Claude Monet:Belle-lle, effet de pluie, 1886, oil on canvas, Bridgestone Museum of Art, Tokyo. Edouard Manet: Le compositeur Chabrier, about 1880, pastel on canvas, Ordrupgaard. Edouard Manet: Corbeille de poires, 1882, oil on canvas, Ordrupgaard. Edouard Manet: Parisienne. Portrait de Madame Jules Guillemet, 1880, pastel on canvas, Ordrupgaard. Source: Illustreret Tidende, no. 38, 1918. 
of the exhibition tells a story in the words of paintings and interiors; a story focalized in the cadence and rhythm of bourgeois beliefs.

Perhaps overstretching the parallels to literary theory, Wilhelm Hansen could also be seen as the more or less direct first-person narrator of the exhibition. But the analogy with literature does not stop here. As several art historians have emphasized, the historical development of the modern novel as character study is also a part of the history of art of the nineteenth century (Nochlin 1971; Clark 1989). As invested in the idea of the individual and of character as we find the romans of Honoré de Balzac (1799-1850) and Gustave Flaubert (1821-1880), the same obsession with individuality and character is found in the thematic sets on the walls of the French gallery at Ordrupgaard and in the appeal to the freely roving spectator. Ultimately, as the first mention of Monsieur Brun made clear, this painting and the totality of the exhibition is parading as a character study of the collector himself: '[...] a discourse whose signifiers he controls and whose referent par excellence is himself,' as the French philosopher Baudrillard (2005: 114) once characterized the relation between collection and collector. In this, Wilhelm Hansen could be seen as both his own author and biographer, using objects to write a narrative ordered in space.

Acknowledging the person of the collector as the element that ties the programme together - as the source of meanings encountered in the exhibition much more than any artwork, painter or sculptor represented - bears more than a casual connection to recently debated problems of 'the curator as producer' (Vidokle 2010; Whitehead 2012: 95). Indeed, along with the work of both historical and present day art curators like Alfred H. Barr jr. (1902-1981), Willem Sandberg (1897-1984), Pontus Hulten (1924-2006), Harald Szeemann (1933-2005) or Hans Ulrich Obrist (b. 1968), Hansen's exhibition as ensemble can be seen as an attempt at making a strong, personal 'intervention' into existing discourses on art, culture and society. In a study of North American collectors Duncan Phillips (1886--1966) and Albert C. Barnes, literary theorist Jeremy Braddock (2012: 6) has argued that:

As provisional institution, the modernist collection was a means of intervening in and reforming cultural practice, doing so on the basis of its form: the collection's aesthetic arrangement, as well as its inclusions and exclusions, was a representation of ideological position.

In Braddock's view, these institutions to-be, encompassing both literary anthologies and 'exhibition-anthologies' of paintings, were meant as vehicles for progressive transformation of society based on the personal investments of the editor/collector. Even though Wilhelm Hansen himself never expressed reformist ambitions as manifestly as collectors like Barnes or Phillips, several other indications of a social agenda are very clear: his introduction of affordable life insurance policies in Denmark and France through the companies Hafnia and La Populaire together with his early involvement in the Volapük-movement for a universal language (Rostrup 1981: 69-71; Fonsmark 2011: 11).

In light of these parallels, it is not difficult to see how the corporeally absent yet ideally present Wilhelm Hansen makes an appeal through the display of his collection that is rhetorically centred on the Manet-portraits and their associated sets of land- and cityscapes; an insistent appeal about the values of modern art and modern middle class life based on ideas of person, personality and character. ${ }^{9}$

\section{Modern spatialities}

Arange of central studies and commentaries on art museums have identified crucial connections with the formulation of a bourgeois subject, identity politics and modernity (e.g. Hooper-Greenhill 1992; Bennett 1995; Maleuvre 1999; Preziosi 2003). In all of these, the organisation of space as a site for the transformation of individuals and community takes on an important role.

As previously mentioned, several spatialities converge in meaningful ways for the visitor to Ordrupgaard around 1919 (as well as today). Heavily built-up city spaces give way to the space of wider, more open roads, and then to the pleasurable space of the open forest, with the gallery rooms at the end of the journey affording an experience of another kind of private, intimate space. There is a feeling of successive stations - of meaningful onward movement 
- in this progression. The hanging of the exhibition rooms further underscores this theme of progression: The first room is dedicated to French painting from the first part of the nineteenth century, especially romantic and Barbizon-painters, the central hall is next, and is dedicated to the largest sub-set of art by Manet and the impressionists, while works by Cézanne and Gauguin conclude the third room. As the last room doubles as library, this could also be seen as a movement in hypostases ultimately culminating in the most densely furnished, most private part of the museum where thoughts and furniture seem equally substantial: a 'site for recollection' (Erinnerungsstätte) as one contemporary German critic writes (Gold 1920), perhaps obliquely referring to the hugely influential teleology of art and spirit to be found in the aesthetics of the German philosopher Hegel (Podro 1982; Wyss 1999). The theme of progression through the exhibition halls was certainly not lost on contemporaries (cf. J.P. 1918; Oppermann 1918a, 1918b; Millech 1919; Hedemann-Gade 1921), bringing echoes of an evolutionary view that was always present in the discipline of art history as it developed in close connection with the museum institution (Whitehead 2012: 75).

In Civilizing Rituals: Inside Public Art Museums from 1995, Carol Duncan proposes to look at the western art museum as a ritual space for the inculcation of citizenship. By focusing on liminality-a concept borrowed from the anthropologist Victor Turner describing the intermediate zone of religious experience - Duncan categorizes art museums as giving templates or scripts for a kind of behaviour that lies outside everyday life (Duncan 1995: 11-12). And following this, one could argue that Hansen's collection, while seemingly supplying a critique of the public art museum by showing an alternative subject and substituting a more intimate, more personal experience, in the end reinforces the very idea of the museum: We go there on a pilgrimage of stations, we move through a progression of zones meant to be setting the right mood, and we prepare and declare ourselves by 'signing in'. Seen from this angle, the viewing of the paintings more or less seems like the way one gives reverence to icons.

A succession of physical spaces - from the outside to the inside of the gallery - leads to a conceptual or ritual space as defined by Duncan. Further related spatial concepts can be identified, and here I am taking the cue from Griselda Pollock's seminal study of 'Modernity and the spaces of femininity', where she places emphasis on how the physical and social spaces demarcated for members of the middle class closely adhere to the motivic spaces in impressionist paintings (Pollock 2003). To a large degree, these spaces of impressionists and their public - the haunts of the haut-bourgeoisie - coincide with those projected at Ordrupgaard ca. 1919. The frame of the ritual space of Hansen's gallery is therefore supplied by the various spatialities expressed in paintings of nature and gardens, tourist spots, modern cityscapes and suburban vistas. Chiefly among these functions, they formulate and perpetuate both the detached gaze of the city-walker in public, the flâneur (Pollock 2003: 94), and the more intimate space of the private citizen's family life through choice of motifs, cropping of scenes and placement of viewpoints. And it is implicitly understood that the system ensuring these pleasures in contemplation of paintings and the leisureladen points of identification implied in the paintings' motifs is based on a social order of modern, western capitalism and the cominginto-existence of the self-sufficient, competent individual.

As these three bourgeois spaces - physical, social and artistic - coexist within the ritual space of the total Ordrupgaard experience, a rather strong resonance is created. Just as the palaces of princes functioned as architectural spectacles supplemented by art works of power and refinement, Ordrupgaard and art works resonate with each other as these overlapping vectors are opened up for the visitor. One crucial difference to past displays of power of course being that total exclusivity has been abandoned: this is instead a project aimed at a general reform of the individual through aesthetics, everyone is welcome to join the world of the middle class, as long as they have the right attitude. As one newspaper wrote in 1918: 'Here are pictures that modern people have to call the best ever painted' (W. 1918, emphasis added). The rowdy, possibly not so modern and not so middle-class crowds attending the nearby track were, however, obviously and explicitly excluded as Ordrupgaard was closed on race-days (W. 1918; also cf. Bennett 1995: 99-102). 


\section{Modernist embodiment}

The museologist Eilean Hooper-Greenhill famously married philosopher Michel Foucault's thoughts about discipline and punishment to the study of the museum (Hooper-Greenhill 1992: 167-190; Foucault 1991). Whether one sees the spatiality of Ordrupgaard along with other public collections as mostly this - a disciplinary instrument - or more as a ritual space aiming at enacted transformation in the vein of Duncan, the effect is either way predicated on societal discourse made manifest through movement in a physical setting. Analyzing the Ordrupgaard experience as a series of spaces reflecting ideas about modernity, art and the good life should serve as a reasonable conclusion to any kind of museological analysis. But absent from this conclusion is a focus on how exhibition discourse goes from passive possibility to active expression in and through subjects. A close consideration of basic levels of experience seems overall to be lacking in some quarters of museology and museum studies involved in historical analysis, even when great attention is otherwise devoted to the formation of subjects. In the following, I therefore explore a possible answer to the 'how' of Wilhelm Hansen's Ordrupgaard by engaging with theories of performativity and collective memory.

In the article 'Exhibition rhetorics: Material speech and utter sense' from 1992, Bruce W. Ferguson is one of the first to propose an analysis that focuses on the exhibition as a performative act in the tradition of the language theorist J.L. Austin (Ferguson 1996). With reference to Ferguson and Austin, one can argue that the exhibition experience involves the active production of a 'reality': an assemblage of paintings in a few rooms is not a simple reflection of some prior 'truth' - whether this is the history of art or what Paris and environs look like - it is a world waiting for its enactment. But a visit to any kind of museum does not just follow a script or mirror a discourse; the visitor actively engages in a performative event that gives latent ideology the fullness of actual experience. Note, instructively, how the often breathless visitor reports written by journalists going to Ordrupgaard in the years 1918-1922 quite conventionally try to convey how the place 'feels'; one journalist, for example, writes of the impressions received by experiencing park, mansion and art collection, but concludes: 'This hasty attempt at a walkthrough cannot possibly convey the beauty which awaits visitors out there' (I.w. 1918). When going to see Wilhelm Hansen's gallery something occurs, a number of feelings and ideas are produced; the exhibition does more than reflect bourgeois modernity, which is then passively received. Through a real and concrete situating moment in time and space - an often pleasurable and sensuous experience - something takes place and becomes 'true' to the participants. By focusing on the active element of the museum visit, I am arguing for a focus on the way that audience and museum together produce meaning out of discourse. And a crucial point here is how the manufacturing discourse is something that exists beyond and prior to subjectivity.

In Judith Butler's work with gender she builds on a crucial insight - initially formulated by the French philosopher Jacques Derrida (Derrida 1988) - that the ground upon which identity is made possible lies with the iteration of norms, rules, codes (Butler 1993: 12-13, 226-227). In Butler's view, gendered identity is an on-going accomplishment, something continuously performed and achieved by the repetition of a set of acts. The shape of these acts is not something singularly willed by the individual, but should rather be seen as a kind of quotation of already existing possibilities. In order for someone to be inscribed with a gendered and sexual identity, their person has to be recognisable within parameters that are known to others and to themselves. 'A fine man' or 'a genuine lady' are performed, whether consciously or not, through gestures, dress, speech and social complexes that are recognisable as markers belonging or not belonging to this or that category. There are real and sometimes unpredictable dangers in being or not being recognisable as 'someone', since a successful performance requires competence and ability to assign meaning not only at the level of the individual, but equally so for the collective. Signing the ledger at the entrance to Ordrupgaard - and thereby announcing/performing your heritage, gendered identity and other, subtle markers accorded to names - is just the most obvious of the performative acts available to and expected by visitors to the collection. Somehow not participating in this and other exhibition appropriate activities carries its own dangers of non-recognition. 
Shifting the focus from sex and gender to identity overall, the same workings clearly apply in belonging to a certain class, having a position, and distinguishing yourself; the battle for which has been widely analyzed in the sociology of power and culture of Pierre Bourdieu (Bourdieu 1993, 1999). In achieving a modern middle class identity-a formation also historically anxious about the assignation of 'appropriate' gender - I propose that memory takes on a defining role. Comprehension in all its forms is predicated on the ability to recall, and in order for someone or something to be comprehensible, he/she/it has to fall within a scope of relations knowable and known. This, of course, leads to a social world defined by a relative persistence of norms and non-norms in repetition; change happens, but happens sporadically. Individuals themselves have miniscule if any direct mastery over processes of identity and comprehension, as they are suspended within meaning-making structures that are defined in the collective. They can only try to 'play along'. As recognition and the achievement of identity take place in sociality and within discourse, then memory itself is not just personal bits and pieces in an idiosyncratic matrix, but structured collectively. Or put in another way: The ability for identity defining acts to constitute a reality lies with the existence of a collective memory.

In How Societies Remember, Paul Connerton makes a sociological analysis based on the theoretical concept of collective memory, which is highly relevant to the on-going discussion. By drawing on the work of the sociologist Maurice Halbwachs (1877-1945), he argues that collective and individual memory is entwined, and that collective memory is both the prerequisite for and the result of performative acts. As he likens performativity to habit, Connerton shows how bodily acts preserve and perpetuate memory itself via repetition and rituals. In dialogue with Halbwachs, Connerton argues for the necessity of objects and physical space to complement and anchor memory since they lend a perceived permanence and stability (Connerton 1989: 37; cf. Pearce 2005: 18-19). Embodiment is in Connerton's view linked to a kind of unconscious learning, and the movement of bodies through anchoring space therefore becomes one of society's most effective ways to build inter-subjective and collective knowledge. Some things cannot be transferred by the listening to myths alone, but has to happen as participatory ritual (Connerton 1989: 54, 57). In this view, any exhibition might become a mnemonic instrument or a parade-ground, and Ordrupgaard a place where artworks, furniture and concrete space lends credibility to ideas.

Reading Butler's definition of identity, performativity and repetition together with Connerton's ideas of performativity as connected to a bodily, collective memory allows a conceptualization of how a site like Hansen's French gallery works. The exhibition visit is the kind of powerful secular ritual (cf. Duncan 1995) suitable to a modern world still cognisant of the proper conduct of rituality but increasingly removed from traditional, participatory religion. Employing this rituality, the exhibition of French art enforces certain habits and memories through the repeated bodily investment of the visitors. To mention some of the most obvious: the scanning of wall-hung paintings through certain movement patterns of back-and-forth, and the adoption of a casual, flâneur-like approach to the world as something to behold and consume; or relating to art works as expressions of character and in need of quick (aesthetic) judgment: the self-portrait of Cézanne at Ordrupgaard 'grave' and 'serious', another of Courbet 'grandiose' and reminiscent of Tizian, while the landscapes by Sisley possess the painter's 'delightful subtlety' (W. 1918; Anonymous 1918). And further: how to display the right ways of dress and comportment, as well as deploying correct and specific ways and subjects of conversation (cf. Rogoff 1998). Underneath this we find an insistent appeal to a modern, middle class individuality of discrete, sensuous aesthetics carried forth by a perambulating gaze.

As exhibition rhetoric (cf. Ferguson 1996), the total Ordrupgaard experience engages with a bourgeois mythology (cf. Barthes 2009), which is elaborated through narrative (cf. Bal 1996); the shape of which is closely allied to the idea of character. The successful performance happens when visitors assimilate themselves into this mythology by producing themselves as bourgeois individuals through physical, embodied investment.

Here, a multitude of conscious and unconscious acts depend on operative knowledge: from visiting within the opening hours, having the money to do so and knowing how to present yourself as a guest both in dress, manners and comportment to spending the right amount of time and talking in the right tone about suitable topics; not asking about the price of the paintings, for example, but duly appraising their individual merits. The quote-like and iterative nature of 
this achievement and its foundation on things already known - not just from the odd article in the newspaper but from being immersed in society - is important in all speheres of life; but in a modern art gallery like Ordrupgaard it carries a special appeal: any relative ignorance of recent French art history is mitigated by the staging of middle class values well-known to the core audience. Alternatively, any individual's perceived deficiency in the manner of a middle class position would ideally be performatively remedied by a successful art-appreciating performance - merit-based admittance to its ranks still being one of the credos of the bourgeoisie. In this way, the Ordrupgaard experience, while pleasurable on many levels, is foremost a machine for the simultaneous acquisition of an expertise in art and a middle class identity. Additionally, of course, it is a field for the promotion of the collection owner, his views on art, his admirable individuality. Judging from the press reception, Hansen as person should always be seen as a prominent and sanctioning feature of the collection.

Summing up, using aspects of Butler's and Connerton's views on performativity provides a theoretically founded explanation that highlights how museum discourse is simultaneously expressed and incorporated by visitors through bodily participation in the exhibition ritual. Working with the visitors' embodiment, a vision of bourgeois modernity is acted out by integrating already known and valued elements: highly desirable connoters of wealth, distinction and respectability serve as background for an intimate framing of the story of modern art. Exhibition experience in this case also allows the repeated expression of feelings and tropes already known through a wider participation in polite society. And as visitors adhere to this rituality in the private museum, it unfolds on the level of the constitutive acts of identity itself - with habitual memory and with iteration.

\section{In conclusion: The pleasures of art and intimacy}

The present article has indulged in an analytical reconstruction of the original Ordrupgaard gallery of French painting as it could be experienced by visitors from the opening in 1918 to the partial sale in 1923. The totality of Ordrupgaard with park, gardens and buildings along with the actual exhibition has been analyzed as an ensemble that stressed pleasurable, experiential encounters with the paintings on display. In concert with the physical surroundings and the artworks themselves, several axes of meaning generating along polarities of new/old, nature/ culture, public/private have been suggested as thematically important for an understanding of the gallery as a 'modernist intervention' in the words of Braddock; an attempt on the part of the collection owner, Wilhelm Hansen, to both influence a Danish reception of art in general, and French nineteenth century painting in particular, and to promote a vision of middle class values. Looking at photographs of the way paintings were displayed, a pattern emerges in which pictures were organized in sets of thematic and narrative distinction. Especially striking is the way portraits are set in relation to other paintings, having the effect of building 'character studies' similar to the modern novel. By way of Pollock and Duncan, the importance of spatiality in the bourgeois social worlds and motifs of French modernism is underlined, and the French gallery is consequently shown as complicit in a specific museum rituality. Questions of how visitors engage at an experiential level is the subject of the final discussion. To answer this, Butler's and Connerton's ideas on performativity, memory and embodiment are considered in order to focus attention on production and maintenance of discourse rather than passive 'mirroring'. From this perspective, visitors actively give latent ideology the fullness of experience by walking, sensing and participating in the museum ritual on the basis of individual and collective memory. From the side of the audience, Ordrupgaard is a mechanism to achieve competence in both bourgeois identity and art appreciation, while simultaneously producing and maintaining both spheres of competence.

In contrast to other public collections in Denmark at the time such as the National Gallery, and the two major museums recently founded on private collections, the Hirschsprung (est. 1911) and the Ny Carlsberg Glyptotek (est. 1897), Ordrupgaard seems closely and explicitly allied to a singular, personal programme of international modernity and bourgeois individuality. The investment in making such a self-assured, clear and well-articulated ensemble as Ordrupgaard should probably also be seen in connection with the fact that impressionism and much post-impressionism had become 'safe' and established movements by the end of WWI. There were other Danish collectors, some of whom built impressive collections of more 
adventurous scope. The art works owned by Johannes Rump (1861-1932) and Christian Tetzen-Lund (1852-1936) included a large selection of pieces by Henri Matisse (1869-1954), Pablo Picasso (1881-1973), Georges Braque (1882-1963) and others and could be described as world-class by any scale - but these were never curated, nor presented as unified and intentionally permanent exhibitions as Wilhelm Hansen did at Ordrupgaard (Monrad 1999). ${ }^{10}$

In examining the case of a small collection museum, I have brought attention to some essential mechanics which to some degree can be found within a range of western art institutions; namely the personalized appeal to visitors as private individuals and the deliberate staging of nature, sensuous materials and art on an intimate, more or less home-like scale; all in order to create pleasant spaces for the performative enactment of middle class identity. As evidenced by the references to the American collectors Duncan Phillips and Albert C. Barnes, contemporary parallel collection museums can be found in which performative embodiment is closely linked to programmes of modern art and bourgeois identity; Karl Ernst Osthaus' (1874-1921) Museum Folkwang in Essen (opened 1902) is another, perhaps extreme, example alongside the Phillips Memorial Gallery (founded 1921) and Barnes Foundation (founded 1922) (Funk-Jones and Müller 1984; Fischer and Schneede 2010). From its early twentieth century format the same strategy can now be seen in a large number of more recent art collections and public museums; a seductive strategy now so common it is hardly noticeable.

A case in point could be the hugely successful Louisiana Museum of Modern Art which was established 40 years later in 1958 in a villa in Humlebæk, 25 kilometers north of Ordrupgaard. The founder, Knud W. Jensen (1916-2000), indirectly acknowledged his indebtedness to the earlier collector by writing his last book on great Danish art collections, in which Wilhelm Hansen is paid ample attention (Jensen 1996). As it is, Louisiana presents one possible culmination of the development of the Ordrupgaard aesthetic: a museum of modern art finely attuned to the pleasurable, ambulatory performance of middle class identity in a sprawling, anti-monumental museum architecture of interlocking and free-flowing spaces integrated with and open to the surrounding park. Much later - Ordrupgaard now a state museum - this development 'returns home' with the addition of the Zaha Hadid wing which lies in direct physical extension of the French gallery, and now presenting the architectural 'face' of the museum. As an idea of museum space, the Hadid addition borrows from Louisiana and other heavily glazed post-WWII museums in being closely integrated with the surrounding landscape. Still, the bare concrete shell - black, polished, organic, envisioned as a line or band half-emerging from the ground - presents more than just a formal contrast to the original Ordrupgaard. While arguably the culmination of a project of cultural 'democratization' first initiated by forward-looking collectors and museum managers like Wilhelm Hansen, it also represents a new era of the spectacle and the spectacular. In the development and transformation from private gallery of a visionary individual to state institution held publicly accountable, some fundamental ideas about art, cultural distinction and 'the good life' have remained, but other equally fundamental institutional changes have obviously taken place - the subject of which will have to await exploration in the future.

Studies of collectors in the modern era have mostly focused on the person of the collector, on relations to discourses on art and in society and on analyzing the way artworks were purchased and displayed. Recent, impressively far-reaching books on the large-scale art collector Helene Kröller-Müller (Rovers 2012) and the collection museum in general (Higonnet 2009), for example, have had less focus on the production of meaning as something necessarily active, as they have often been more interested in searching for what that meaning may be characterized as. But without an engaged, theoretically sound and functioning way to explain the broad communicative act involving senses, sensuality, memory and identity that may also be considered part of an exhibition, we only work with parts of the equation. In the light of so little data in the form of surveys and visitor studies available when discussing exhibitions of the past, we are in need of a well-founded perspective on the creation of meaning in experience; something which so many otherwise brilliant historical studies mainly infer. I hope the present exploration has opened new vistas on ways to grasp historical exhibitions as functioning spaces; spaces for the performative production and maintenance of identity. This focus certainly does not repudiate previous efforts, but it might broaden our attempts at understanding concrete developments and transformations in and of the bourgeois exhibition space throughout the last 
century. As such, the analytical interweaving of semantic, phenomenological and performative concerns in this article is just a sketch of how such studies may be pursued; a proposed way of seeing how discourse is activated and becomes embodied, actual and palpable in the modern exhibition.

Received: 13 September 2013

Finally accepted 13 August 2014

\section{Notes}

1 This re-imagination of a visit is a composite based on photographs of park and mansion in the archive at Ordrupgaard from 1918, 1921, 1922 and 1931 (a few of them re-produced here), first-hand experience in the present (2013-14) and descriptions in the press from 1918-1922 (see references further on; Anonymous 1918 and Millech 1919 supply some of the most direct descriptions).

2 Madsen's short introductory essay clearly establishes the categories of 'romantics', 'realism', 'modernism' and 'impressionists' along with 'the school of 1830', another designation for the Barbizon school rarely met today, as categories for understanding the art on display (Madsen 1918: 6-8).

3 The assessment of lesser quality of the second French collection is of course subjective but is generally expressed in later literature (cf. Rostrup 1981; Asmussen 1993; Fonsmark 2011). Wilhelm Hansen's personal reaction to the economic troubles surrounding the sale seems to have been a mixture of regret and resolve. A number of letters to his wife detail his quest to sell his paintings swiftly (Asmussen 1993: 27-8). Later writers like Rostrup, who as a young man knew Wilhelm Hansen, seem to think he felt badly treated by both the press and the establishment, and tend to see this feeling expressed in the limits put on the public's access after the sale of half the collection (1981: 34). Any deliberate strategies for re-building the collection are not documented.

4 The relevant material is kept at the archive at Ordrupgaard. There are, of course, limits to what written and photographic sources can and normally will reveal. A problem with all archival material has to do with what is normally left out since it is seen as too tedious, insignificant, difficult or personal to record - daily life in general, private conversations, feelings and sensations - and from the inherent bias in different types of media. Letters, photographs, account ledgers and so forth all have special characteristics that shape and frame what is being recorded. Re-imagining and reconstructing the past on a partly phenomenological basis through an interpreter's own experiences might point to insights normally lacking from traditional records. This approach certainly carries its own challenges - especially as it is based on a belief in a fundamental continuity and inter-subjectivity between individuals past and present. In the context of Ordrupgaard, I am willing to risk imagining some of the sensory impressions people might possibly have experienced about 100 years ago.

5 Although impressionist and French modernist painting had been exhibited in Copenhagen since 1888 - Gauguin had even had his first solo presentation in the city as early as 1885 - public collections were slow to acquire and display this kind of art. Not until after the death of the somewhat conservative founder Carl Jacobsen (1842-1914), did Ny Carlsberg Glyptotek gradually start to give its wholehearted attention to the subject through the effort of his son, Helge Jacobsen (1882-1946), who became its director and chairman of the board (Munk 1993). Today, Ordrupgaard is the only other museum in Denmark with a collection of nineteenth century French painting and sculpture since, due to peculiar historical circumstances, the National Gallery of Denmark focuses on the avant-garde of the early twentieth century.

6 While both gallery and mansion compare to the international trend of collection museums 
there is very little source material suggesting direct inspiration for exteriors and interiors from, for example, the Wallace Collection in London or Fenway Court in Boston (today Isabella Stewart Gardner Museum) or in general from the abodes of international high society; these can only be inferred. The bureau of Gotfred Tvede, an accomplished and experienced architect to society's wealthiest members, should instead probably be seen as the origin of much of the overall stylistic choices - probably as a range of available solutions then finally decided upon by Wilhelm and his wife Henny. To gather inspiration, Tvede did visit the home and gallery of one major collector, the Swede Klas Fåhræus (Tvede 1921), whose house on the island of Lidingö outside Stockholm still stands, but who lost his collection in the middle of the 1920'es. Its heavy Scandinavian national romantic style with a castle-like exterior was decidedly not an inspiration. A final and obvious source of inspiration would have come from the commercial exhibitions of Parisian dealers like Bernheim-Jeune, Petit and Durand-Ruel. All in all, there are no sources pointing to anyone in any particularly strong or influential advisory position to Wilhelm Hansen.

$7 \quad$ Almost all original furniture seen in contemporary photographs of Hansen's collection has survived to this day and is a part of Ordrupgaard's official holdings. Though some are seemingly genuine, historical pieces, they have no known provenance.

8 As a young man, Hansen received crucial training with the prestigious Gresham Life Assurance whose Copenhagen office he came to manage in 1891 (Fonsmark 2011: 11). Hansen also travelled in England, and this early connection to British culture could be seen as shaping a later wish to emulate parts of an aristocratic lifestyle with British aspirations.

9 Photographs from 1931 show that Hansen also orchestrated an ensemble-like hanging of his second and numerically reduced French collection. Without the important anchoring portraits by Manet - and less important portraits by Toulouse-Lautrec, Degas and others - the centre of gravity shifted to landscapes.

10 At the time, there was already a general awareness that economic conditions during the war had triggered unprecedented Danish collecting activity in the field of international modern art (Hafniensis 1918; J.P. 1918; Kragh 1918). Considering the collective activities of collectors like Hansen, Tetzen-Lund and Rump together with activities like those of Herwarth Walden (1879-1941), foremost promoter of avant-garde art, Copenhagen has retrospectively been seen as a short-lived European center for progressive art during the war (Aagesen et al. 2002).

\section{Bibliography}

Aagesen, D., Abildgaard, H., Zerlang, M. \& Warming, R. (2002) The Avant-garde in Danish and European Art 1909-19, Copenhagen: Statens Museum for Kunst.

Anonymous (1918) 'Indvielsen af Ordrupgaards franske Malerisamling', Berlingske Tidende, 15 September, p. 8

Anonymous (1921a) 'Nogle Billeder fra Parken omkring den smukke Ejendom Ordrupgaard', Vore Damer, 9 (15), unpaginated.

Anonymous (1921b) 'Nogle Interiører fra Etatsraad Wilhelm Hansens smukke Hjem Ordrupgaard', Vore Herrer, 6 (16), unpaginated.

Asmussen, M.W. (1993) Wilhelm Hansens oprindelige franske samling på Ordrupgaard I Wilhelm Hansen's original French collection at Ordrupgaard, København: Munksgaard. 
Bal, M. (1996) 'The discourse of the museum' in R. Greenberg, B.W. Ferguson \& S. Nairne, (eds) Thinking about Exhibitions, pp. 201-218, New York, NY: Routledge.

Bal, M. (2002) Travelling Concepts in the Humanities: A Rough Guide, Toronto: University of Toronto Press.

Bal, M. (2009) Narratology: Introduction to the Theory of Narrative, 3rd edn, Toronto: University of Toronto Press.

Barthes, R. (2009) 'Myth today' in Mythologies, London: Vintage.

Baudrillard, J. (2005) The System of Objects, London: Verso.

Bennett, T. (1995) The Birth of the Museum: History, Theory, Politics, London: Routledge.

Bourdieu, P. (1993) The Field of Cultural Production, Cambridge: Polity Press.

Bourdieu, P. (1999) Distinction: A Social Critique of the Judgment of Taste, London: Routledge.

Braddock, J. (2012) Collecting as Modernist Practice, Baltimore, MD: The Johns Hopkins University Press.

Butler, J. (1993) Bodies that Matter: On the Discursive Limits of 'Sex', London: Routledge.

Clark, T.J. (1989) The Painting of Modern Life: Paris in the Art of Manet and his Followers, Princeton, NJ: Princeton University Press.

Connerton, P. (1989) How Societies Remember, Cambridge: Cambridge University Press.

Derrida, J. (1988) 'Signature Event Context' in Limited Inc., Evanston, ILL: Northwestern University Press.

Derrida, J. (2001) 'Structure, sign and play in the discourses of the human sciences' in Writing and Difference, New York: Routledge.

Dumonthier, E. (1922) 'Une grande collection d'oeuvres françaises modernes en Danemark: La collection Wilhelm Hansen', La Revue de l'art ancien et moderne, XLII (241), pp. 331-343.

Duncan, C. (1995) Civilizing Rituals: Inside Public Art Museums, London: Routledge.

Duret, T. (1906) Histoire des peintres impressionistes: Pissarro, Claude Monet, Sisley, Renoir, Berthe Morisot, Cézanne, Guillaumin, Paris: H. Floury.

Elkins, J. (1999) Pictures of the Body: Pain and Metamorphosis, Stanford, CA: Stanford University Press.

Entman, R.M. (1993) 'Framing: Toward clarification of a fractured paradigm', Journal of Communication, 43 (4), pp. 51-58.

Ferguson, B.W. (1996) 'Exhibition rhetorics: Material speech and utter sense' in R. Greenberg, B.W. Ferguson \& S. Nairne, (eds) Thinking about Exhibitions, pp. 175190, London: Routledge.

Fischer, H. \& Schneede, U.M. (eds) (2010) 'Das schönste Museum der Welt'- Museum Folkwang bis 1933, Göttingen: Edition Folkwang / Steidl. 
Fonsmark, A. (2011) 'Introduction: Wilhelm Hansen's Collection of French Art at Ordrupgaard' in A. Fonsmark (ed) French Art at Ordrupgaard: Complete Catalogue of Paintings, Sculptures, Pastels, Drawings, and Prints, pp. 11-23, Ostfildern: Hatje Cantz.

Foucault, M. (1991) Discipline and Punish: The Birth of the Prison, London: Penguin Books.

Funk-Jones, A. \& Müller, J.H. (eds) (1984) Die Folkwang-Idee des Karl Ernst Osthaus: Karl Ernst Osthaus Museum, Hagen, Hagen: Karl Ernst Osthaus Museum.

Fåhræus, K. (1918) 'Manet-Samlingen i Ordrupgaard', Kunstmuseets Aarsskrift, vol. 1918, pp. 2-12

Gallagher, S. \& Zahavi, D. (2008) The Phenomenological Mind: An Introduction to Philosophy of Mind and Cognitive Science, London: Routledge.

Gold, A. (1920) ,Kunst und Sammler in Dänemark und Skandinavien', Der Cicerone: Halbmonatsschrift für Künstler, Kunstfreunde und Sammler, 12 (24), pp. 871-878.

Haagen (1918) 'Den franske Kunstsamling paa Ordrupgaard', Vore Damer, 6 (22), unpaginated.

Habermas, J. (1991) The Structural Transformation of the Public Sphere: An Inquiry into a Category of Bourgeois Society, Cambridge, MA: MIT Press.

Hafniensis (1918) 'Bref från Köpenhamn', Sydsvenska Dagbladet, 30 September, p. 5

Hedemann-Gade, H. (1921) 'Ordrupgaardsamlingen: En Exkursion i franskt 1800-talsmåleri', Tidskrift för Konstvetenskap, vol .VI, pp. 1-14.

Higonnet, A. (2009) A Museum of One's Own: Private Collecting, Public Gift, Pittsburgh, PA; New York: Periscope.

Hooper-Greenhill, E. (1992) Museums and the Shaping of Knowledge, New York: Routledge.

J.P. (1918) 'Ordrupgaards Samling af fransk Kunst: Aabningshøjtideligheden i Gaar', Socialdemokraten, 15 September, p. 5

Jensen, K.W. (1996) De glade givere, Copenhagen: Gyldendals bogklubber.

Klonk, C. (2009) Spaces of Experience: Art Gallery Interiors from 1800 to 2000, New Haven, MA: Yale University Press.

Kragh J. (1918) 'Fransk Kunst hos os: Efteraaret 1918', Hovedstaden, 28 October, pp. 4-5

Larsen, P.N. (2002) 'Painterly perception and images of the soul: Impressionism and postimpressionism in Denmark' in T. Gunnarsson \& P. Hedström (eds) Impressionism and the North: Late 19th century French Avant-garde Art and the Art in the Nordic Countries 1870-1920,pp. 158-203, Stockholm: Nationalmuseum.

Lévi-Strauss, C. (1969) The Elementary Structure of Kinship, Boston, MA: Beacon Press.

Levy, C. (1921) 'Endnu nogle flere Billeder fra Etatsraad Wilhelm Hansens Ejendom Ordrupgaard', Vore Damer, 9 (16), unpaginated.

I.w. (1918) 'Den franske Samling paa Ordrupgaard', København, 15 September, p. 5 
Madsen, K. (1918) Malerisamlingen Ordrupgaard, Wilhelm Hansens samling. Malerier, akvareller, pasteller, tegninger af franske kunstnere, Copenhagen: Ordrupgaard.

Madsen, K. (1920) 'Fransk malerkunst i Danmark' in Bogen til Frankrig, pp. 17-26, København: Martins Forlag.

Maleuvre, D. (1999) Museum Memories: History, Technology, Art, Stanford, CA: Stanford University Press.

Meier-Graefe, J. (1907) Impressionisten: Guys, Manet, Van Gogh, Pissarro, Cézanne, München: R. Piper.

Millech, K. (1919) 'Malerisamlingen Ordrupgaard', Klingen, 2 (1), unpaginated.

Monrad, K. (ed) (1999) Matisse: Four Great Collectors, Copenhagen: Statens Museum for Kunst.

Munk, J.P. (1993) French Impressionism: Ny Carlsberg Glyptotek: Catalogue, Copenhagen: Ny Carlsberg Glyptotek.

Nochlin, L. (1971) Realism, Harmondsworth: Penguin Books.

O'Doherty, B. (1999) Inside the White Cube: The Ideology of the Gallery Space, Berkeley, CA: University of California Press.

Oppermann C. R. T. (1918a) 'Malerisamlingen paa Ordrupgaard: Fransk Malerkunst fra det 19de Aarhundrede', Berlingske Tidende, 3 October, Evening edition, p. 3

Oppermann C. R. T. (1918b) 'Malerisamlingen paa Ordrupgaard: II. Impressionisterne, Gauguin og Cézanne', Berlingske Tidende, 7 October, Evening edition, pp. 3-4

Pearce, S.M. (2005) On Collecting: An Investigation into Collecting in the European Tradition, London: Routledge.

Perrot, M. (ed) (1990) A History of Private Life, Volume IV: From the Fires of Revolution to the Great War, Cambridge, MA: Belknap Press.

Podro, M. (1982) The Critical Historians of Art, New Haven, MA: Yale University Press.

Pollock, G. (2003) 'Modernity and the spaces of femininity' in Vision and Difference: Femininity, Feminism and Histories of Art, pp. 70-127, London: Routledge.

Preziosi, D. (2003) Brain of the Earth's Body: Art, Museums, and the Phantasms of Modernity, Minneapolis, MN: University of Minnesota Press.

Rogoff, I. (1998) 'How to dress for an exhibition' in M. Hannula (ed) Stopping the Process? Contemporary Views on Art and Exhibitions, pp. 130-149, Helsinki: The Nordic Institute for Contemporary Art.

Rostrup, H. (1981) Histoire du Musée d'Ordrupgaard: D'après des documents inédits, Copenhagen: Ordrupgaard.

Rovers, E. (2012) De eeuwigheid verzameld: Helene Kroiller-Muiller (1869-1939), Amsterdam: Bakker.

Tvede, G. (1921) 'Ordrupgaard', Architekten, XXIII (13), pp. 205-212.

Vidokle, A. (2010) 'Art without artists?', e-flux journal, [Online], 2010 (16) http://www.e-flux. com/journal/art-without-artists/. 
Villadsen, V. (1998) Statens Museum for Kunst: 1827-1952, København: Statens Museum for Kunst.

W. (1918) 'Ordrupgaards Malerisamling aabnedes i Gaar', Politiken, 15 September, p. 9-10

Weintraub, J. (1997) 'The theory and politics of the public/private distinction' in J. Weintraub \& K. Kumar (eds) Public and Private in Thought and Practice: Perspectives on a Grand Dichotomy,pp 1-42, Chicago, IL: The University of Chicago Press.

Whitehead, C. (2012) Interpreting Art in Museums and Galleries, London: Routledge.

Wyss, B. (1999) Hegel's Art History and the Critique of Modernity, Cambridge: Cambridge University Press.

* Rasmus Kjærboe has an MA Research Degree in art history from Copenhagen University and is a PhD fellow at Aarhus University and Ordrupgaard, Copenhagen. His project seeks to interpret the development of the early twentieth century collection museum of modern art in Europe and USA. Kjærboe is the Vice-President of the Danish Association of Art Historians and editor of Kunsthistorisk Bogliste, the Danish art historical book review.

Contact information:

Rasmus Kjærboe

Toftegaards Alle 7, 2. N

DK-2500 Valby

rkj@arthistory.dk

+4530208464 